\title{
Praca kobiet w gospodarstwie domowym wyzwaniem dla prawa pracy i dla prawa ubezpieczeń społecznych
}

\section{Wstęp}

Sytuacja kobiet pracujących $\mathrm{w}$ domu $\mathrm{z}$ oczywistych względów przedstawia się odmiennie od tej, w jakiej znajdują się kobiety pracujące zawodowo. „Strażniczki domowego ogniska” nie otrzymują wynagrodzenia za czynności wykonywane $\mathrm{w}$ ramach prowadzenia gospodarstwa domowego, nie wypracowują tym samym prawa do własnej emerytury. W dyskusji dotyczącej tego problemu, często pojawia się więc kwestia przyszłości kobiet, które ze względu na zaangażowanie w obowiązki rodzicielskie, $\mathrm{w}$ wieku poprodukcyjnym, mają problem z zachowaniem niezależności ekonomicznej i zagrożone są ubóstwem oraz przemocą, zwłaszcza o charakterze ekonomicznym².

W związku z tym, w literaturze coraz częściej analizuje się zjawisko nieodpłatnej pracy kobiet. Przedstawiane są dane dotyczące czasu, jaki kobiety przeznaczają na poszczególne usługi i wycenia ich wartość rynkową. Na ich podstawie szacuje się, że wartość nieodpłatnej pracy w domu kształtuje się na poziomie $30 \%$ wartości $\mathrm{PKB}^{3}$. Podkreśla się również, że gdyby nagle zabrakło nieodpłatnej pracy kobiet, państwo zostałoby postawione przed koniecznością szybkiej i gruntownej przebudowy polityki społecznej ${ }^{4}$.

\footnotetext{
${ }^{1}$ Doktorantka, Uniwersytet Łódzki, Wydział Prawa i Administracji, Katedra Prawa Pracy.

${ }^{2}$ A. Dryjańska, Nieodpłatna praca kobiet: różowa strefa gospodarki, [w:] Nieodpłatna praca kobiet: różowa strefa gospodarki, A. Dryjańska, J. Piotrowska (red.), Warszawa 2012, s. 9; J. Szachowicz-Sempruch, Nieodplatna praca $w$ domu i polityka rodzinna jako formy przemocy instytucjonalnej, http://search.ebscohost.com.ebscohostresearchdatabasestest0.han3.lib.uni. lodz.pl.ebscohostresearchdatabasestest0.han3.lib.uni.lodz.pl/login.aspx?direct $=$ true $\& \mathrm{db}=\mathrm{b}$ th\&AN=118412854\&lang=pl\&site=eds-live (dostęp: 09.04.2017); E. Lisowska, Przemoc ekonomiczna wobec kobiet, Obserwatorium Równości Płci, http://rownoscplci.pl/uploads/filemanager/ Nowy\%20folder/przemocekonomicznawobeckobiet.pdf (dostęp: 09.04.2017).

${ }^{3}$ A. Dryjańska, op. cit., s. 5; por. także: M. Marszałek, Rola kobiet i mężczyzn w tworzeniu nierynkowej produkcji gospodarstw domowych - rekomendacje dla polityki rodzinnej, http://search. ebscohost.com.ebscohostresearchdatabasestest0.han3.lib.uni.lodz.pl.ebscohostresearchdatabasestest0.han3.lib.uni.lodz.pl/login.aspx?direct $=$ true $\& d b=b$ th \&AN $=102124633 \&$ lang $=$ pl\&site=eds-live (dostęp: 09.04.2017); I. Błaszczak-Przybycińska, Wartość pracy domowej - wycena empiryczna na podstawie ogólnopolskiego badania budżetu czasu ludności, http://search.ebscohost.com.ebscohostresearchdatabasestest0.han3.lib.uni.lodz.pl.ebscohostresearchdatabasestest0. han3.lib.uni.lodz.pl/login.aspx?direct $=$ true $\& d b=b t h \& A N=102124632 \&$ lang $=$ pl\&site $=$ eds-live (dostęp: 09.04.2017).

${ }^{4}$ A. Dryjańska, op. cit., s. 5.
} 
Nie sposób nie dostrzec, że faktycznie praca kobiet wykonywana w domu, traktowana jest jako przynależąca do sfery prywatnej jednostki i przez to staje się często „niewidzialna” zwłaszcza dla osób, które czerpią najwięcej z jej owoców, wręcz traktowana jest jak obowiązek, którego prawidłowa realizacja poddana jest kontroli społecznej w stopniu większym, niż ma to miejsce w przypadku mężczyzn ${ }^{5}$.

Takie postrzeganie pracy kobiet wpływa na ich pozycję na gruncie prawa ubezpieczeń, a zwłaszcza na możliwość wypracowania prawa do własnej emerytury i jej wysokość. Wskazują na to liczne badania ujawniające dysproporcje w dochodach kobiet i mężczyzn, przerwy w zatrudnieniu związane ze sprawowaniem osobistej opieki nad dzieckiem lub chorym członkiem rodziny, a także na częstsze niż w przypadku mężczyzn zatrudnienie w niepełnym wymiarze czasu pracy ${ }^{6}$.

W związku z tym warto zastanowić się, w jaki sposób wzmacniać pozycję prawną kobiet prowadzących gospodarstwo domowe, w szczególności rozważenia wymaga kwestia oceny postulatów regulacji prawnej pracy wykonywanej w domu i zabezpieczenia emerytalnego kobiet angażujących się w opiekę nad członkami rodziny, a także wpływu dyskryminacji kobiet w zatrudnieniu na wysokość świadczeń emerytalnych i rozdział obowiązków domowych oraz rodzicielskich.

$\mathrm{Na}$ te pytania postaram się odpowiedzieć w niniejszym artykule przedstawiając dane obrazujące sytuację kobiet na rynku pracy oraz wybrane regulacje z zakresu prawa pracy oraz prawa ubezpieczeń społecznych, mające wpływ na położenie prawne kobiet biernych zawodowo oraz pracujących w niepełnym wymiarze czasu pracy, ze względu na zaangażowanie w prowadzenie gospodarstwa domowego i opiekę nad bliskimi.

\footnotetext{
${ }^{5}$ Por. A. Titkow, D. Duch-Krzystoszek, B. Budrowska, Nieodpłatna praca kobiet. Mity, realia, perspektywy, Warszawa 2004, s. 33. Autorzy wskazują, że nieodpłatna praca kobiet nie funkcjonuje jako kategoria dyskursu publicznego, w efekcie czego pozostaje jedynym, podstawowym, nie podlegającym kontroli świata zewnętrznego desygnatem sfery prywatnej.

${ }^{6}$ Główny Urząd Statystyczny, Różnice w wynagrodzeniach kobiet i mężczyzn w Polsce (stan w 2014 roku), Główny Urząd Statystyczny. Portal Informacyjny, http://stat.gov.pl/obszary-tematyczne/ rynek-pracy/pracujacy-zatrudnieni-wynagrodzenia-koszty-pracy/roznice-w-wynagrodzeniachkobiet-i-mezczyzn-w-polsce-stan-w-2014-roku,132242,1.html (dostęp: 17.04.2017); por. także: Struktura wynagrodzeń wedtug zawodów w październiku 2014 r., Główny Urząd Statystyczny. Portal Informacyjny, http://stat.gov.pl/obszary-tematyczne/rynek-pracy/pracujacy-zatrudnieniwynagrodzenia-koszty-pracy/struktura-wynagrodzen-wedlug-zawodow-w-pazdzierniku2014-r-,5432,4.html (dostęp: 30.10.2016); Kobiety i mężczyźni na rynku pracy 2016, Główny Urząd Statystyczny. Portal Informacyjny, http://stat.gov.pl/obszary-tematyczne/rynek-pracy/ opracowania/kobiety-i-mezczyzni-na-rynku-pracy-2016,1,64.html (dostęp: 17.04.2017); Praca a obowiązki rodzinne w 2010 r., Główny Urząd Statystyczny. Portal Informacyjny, http://stat.gov. pl/obszary-tematyczne/rynek-pracy/opracowania/praca-a-obowiazki-rodzinne-w-2010-r-,3,2. html (dostęp: 17.04.2017).
} 


\section{Zabezpieczenie emerytalne kobiet a dyskryminacja ze względu na płeć}

Podnosząc kwestię zabezpieczenia emerytalnego kobiet warto wskazać, że kobiety aktywne zawodowo napotykają na problem tzw. luki płacowej, czyli dysproporcji w wynagrodzeniach kobiet i mężczyzn, mającej również wpływ na wysokość przyszłych emerytur. Problem luki płacowej chociaż bezpośrednio dotyka kobiety pracujące zawodowo, ma bez wątpienia także wpływ na sytuację kobiet pracujących w domu. Kobiety zarabiają mniej i w związku z tym częściej niż mężczyźni rezygnują z kariery, aby poświęcić się rodzinie albo decydują się na pracę w niepełnym wymiarze czasu pracy. To z kolei rodzi u pracodawców niechęć do zatrudniania kobiet - zwłaszcza na dobrze opłacanych stanowiskach kierowniczych - gdyż wiążą się one zwykle z większą odpowiedzialnością i potrzebą dyspozycyjności, a także do pomijania kobiet przy awansach i typowaniu do udziału w szkoleniach podnoszących kwalifikacje zawodowe. Pracodawcy obawiają się bowiem inwestowania $\mathrm{w}$ pracownika, który może mieć problem z godzeniem życia zawodowego i rodzinnego ${ }^{7}$.

Problem ten został dostrzeżony m.in. przez Rzecznika Praw Obywatelskich, który wskazywał, że kobiety zatrudniane są w gorzej opłacanych sektorach gospodarki, przede wszystkim w sektorze usług opiekuńczych ${ }^{8}$. Takie stwierdzenie potwierdzają dane zgromadzone przez Główny Urząd Statystyczny, które wskazują, że najbardziej sfeminizowanymi sektorami gospodarki są: opieka zdrowotna i pomoc społeczna oraz edukacja - w tych sekcjach gospodarki narodowej kobiety stanowią ok. 8 na 10 pracujących ${ }^{9}$. Zjawisko luki płacowej, jak podkreśla RPO, wynikać może także ze stereotypowych opinii o braku predyspozycji kobiet do wykonywania zawodów technicznych lub sprawowania funkcji kierowniczych, a także z niższych wynagrodzeń za godzinę (w $2014 \mathrm{r}$. wskaźnik Gender Pay Gap ${ }^{10}$ dla Polski wyniósł 7,7 co oznacza, że za godzinę pracy kobiety zarabiały średnio o $7,7 \%$ mniej od mężczyzn) ${ }^{11}$, mniejszej liczby godzin przepracowanych na płatnych stanowiskach oraz niższej stopy zatrud-

\footnotetext{
${ }^{7}$ Por. także: U. Jackowiak, Sytuacja pracownicza kobiet, Gdańsk 1994, s. 10-11.

${ }^{8}$ RPO: Niższe wynagrodzenia kobiet efektem nierówności w życiu społecznym, „Gazeta Prawna”, http://serwisy.gazetaprawna.pl/praca-i-kariera/artykuly/9296628,rpo-wynagrodzenia-kobiet-praca.html (dostęp: 30.10.2016).

${ }^{9}$ Kobiety i mężczyźni na rynku pracy, Główny Urząd Statystyczny. Portal Informacyjny, http:// stat.gov.pl/obszary-tematyczne/rynek-pracy/opracowania/kobiety-i-mezczyzni-na-rynkupracy-2016,1,6.html (dostęp: 30.10.2016).

${ }^{10}$ Gender Pay Gap (GPG), czyli wskaźnik zróżnicowania wynagrodzeń ze względu na płeć - jest to różnica między przeciętną godzinową stawką wynagrodzenia brutto mężczyzn i kobiet wyrażona przez procent przeciętnej godzinowej stawki wynagrodzenia brutto mężczyzn.

${ }^{11}$ Różnice $w$ wynagrodzeniach kobiet $i$ mężczyzn w Polsce (stan w 2014 r.), Główny Urząd Statystyczny. Portal Informacyjny, http://stat.gov.pl/obszary-tematyczne/rynek-pracy/pracujacyzatrudnieni-wynagrodzenia-koszty-pracy/roznice-w-wynagrodzeniach-kobiet-i-mezczyzn-wpolsce-stan-w-2014-roku,12,1.html (dostęp: 30.10.2016).
} 
nienia. Ponadto wśród kobiet jest wyższy odsetek pracujących najemnie i pomagających bezpłatnie członkom rodzin, niższy natomiast pracujących na własny rachunek i pracodawców. Kobiety pracują także ponad dwukrotnie częściej niż mężczyźni w niepełnym wymiarze czasu pracy (10,7\% spośród nich pracuje w niepełnym wymiarze, podczas gdy mężczyźni w tej kategorii stanowią tylko $4,7 \%$ ). Co istotne dla oceny tego zjawiska - 13,1\% kobiet (w przypadku mężczyzn tylko 3,3\% spośród nich) pracujących w niepełnym wymiarze czasu pracy, jako przyczynę tego stanu rzeczy wskazuje konieczność opieki nad dziećmi, innymi osobami oraz inne powody osobiste i rodzinne. Nie dziwi zatem fakt, że pracodawcy obawiają się ryzyka socjalnego związanego z zatrudnianiem kobiet, gdyż w dalszym ciągu to na nich spoczywają w większym stopniu obowiązki związane z pełnieniem funkcji rodzicielskiej.

Także w literaturze przedmiotu poszukuje się przyczyn istniejących dysproporcji w strukturze zatrudnienia wskazując, że wpływ na nią ma m.in. dyferencjacja w zakresie poziomu i rodzaju kwalifikacji zawodowych według kryterium płci, co z kolei jest konsekwencją nieprawidłowej struktury kształcenia. W konsekwencji, wobec braku odpowiedniego przygotowania zawodowego, kobiety zostają wyeliminowane $\mathrm{z}$ rynku pracy $\mathrm{w}$ wielu gałęziach i zawodach, co tylko utrwala tradycyjne zdominowanie przez przedstawicieli jednej z płci niektórych zawodów, a nawet branż ${ }^{12}$.

Zjawisko luki płacowej wpisuje się zaś w szerszy problem jaki stanowi dyskryminacja ze względu na płeć. Ustawodawca stara się przeciwdziałać praktykom dyskryminacyjnym podnosząc zasadę równego traktowania pracowników oraz zasadę niedyskryminacji do rangi podstawowych zasad prawa pracy. Zgodnie z art. $11^{2}$ ustawy z dnia 26 czerwca 1974 r. Kodeks pracy ${ }^{13}$,pracownicy mają równe prawa $z$ tytułu jednakowego wypełniania takich samych obowiązków, co dotyczy w szczególności równego traktowania kobiet i mężczyzn w zatrudnieniu".

Natomiast zasada niedyskryminacji w zatrudnieniu odnosi się do sformułowanej w art. 32 ust. 2 Konstytucji Rzeczypospolitej Polskiej ${ }^{14} \mathrm{z}$ dnia 2 kwietnia 1997 r. zasady niedyskryminacji i jest zasadą komplementarną w stosunku do zasady równego traktowania $\mathrm{W}$ zatrudnieniu ${ }^{15}$. W doktrynie podkreśla się również, że stanowi ważny element prawa do pracy oraz odnosi się do zasady poszanowania dóbr osobistych w zatrudnieniu, gdyż zgodnie ze stanowiskiem wyrażonym przez $\mathrm{SN}$, dyskryminacja związana jest z naruszeniem godności człowieka, której poszanowanie stanowi nakaz nie tylko prawny, lecz także mo-

\footnotetext{
${ }^{12}$ U. Jackowiak, op. cit., s. 24-27.

${ }^{13}$ Ustawa z dnia 26 czerwca 1974 r. Kodeks pracy, tekst jedn. Dz.U. z 2016 r., poz. 1666.

${ }^{14}$ Konstytucja Rzeczypospolitej Polskiej z dnia 2 kwietnia 1997 r., Dz.U. Nr 78, poz. 483.

${ }^{15}$ W. Perdeus, Komentarz do art. 113 k.p., [w:] Kodeks pracy. Komentarz, K.W. Baran (red.), Warszawa 2016, s. 102-103.
} 
ralny ${ }^{16}$. Zgodnie z treścią tej zasady niedopuszczalna jest jakakolwiek dyskryminacja w zatrudnieniu, bezpośrednia lub pośrednia, w szczególności ze względu na m.in. płeć.

Rozwinięciem i konkretyzacją, a zarazem kluczowym przepisem odnoszącym się bezpośrednio do równości w zakresie płac, jest natomiast art. $18^{3 \mathrm{c}}$ k.p. Takie stwierdzenie znajduje uzasadnienie w stanowisku SN, który w wyroku z dnia 29 listopada 2012 r. stanowi, iż wynikająca z art. $18^{3 \mathrm{c}}$ k.p. zasada jednakowego wynagradzania pracowników, jest rozwinięciem ogólnego zakazu dyskryminacji ${ }^{17}$. Powoływany przepis stanowi, że pracownicy mają prawo do jednakowego wynagrodzenia za jednakową pracę lub za pracę o jednakowej wartości. Redakcja tego przepisu skłania do rozważenia, po pierwsze, jak rozumieć należy pojęcia: „praca jednakowa” oraz „praca jednakowej wartości”, po drugie, czy ustawodawca celowo abstrahuje w treści art. $18^{3 \mathrm{c}} \mathrm{k}$.p. od wskazanych $\mathrm{w}$ innych przepisach k.p. kryteriów dyskryminacyjnych, tym samym wymagając równości absolutnej w przypadku porównywania prac jednakowych lub o jednakowej wartości ${ }^{18}$.

Pojęcia „pracy jednakowej wartości” zostało określone przez SN, który utożsamia je z pracami takimi samymi pod względem rodzaju, kwalifikacji koniecznych do ich wykonywania, warunków, w jakich są świadczone, a także ich ilości i jakości ${ }^{19}$.

Jeśli chodzi natomiast o drugą kwestię, to należy zgodzić się z zaprezentowanym w orzecznictwie poglądem, który nakłada na pracownika podnoszącego zarzut dyskryminacji w zakresie wynagradzania obowiązek wykazania zarówno mniej korzystnego wynagradzania w stosunku do innych pracowników wykonujących pracę jednakową lub pracę jednakowej wartości, jak i zróżnicowania spowodowanego niedozwoloną przyczyną, co prowadzi do wniosku, że warunkiem sine qua non dalszego postępowania jest istnienie określonej przyczyny dyskryminacji ${ }^{20}$. Tylko pracownik wykonujący pracę jednakową lub jednakowej wartości, mający wynagrodzenie ukształtowane na niższym poziomie niż inny pracownik, jeżeli ta różnica wynika z jednej lub kilku przyczyn, o których mowa w art. $18^{3 a} \S 1$ k.p., może być uznany za dyskryminowanego, gdyż zarówno przepisy zawarte w rozdziale IIa k.p., jak i prawo UE nie zawierają normy, z której miałoby wynikać, że wszyscy pracownicy danego pracodawcy mają

\footnotetext{
${ }^{16}$ Wyrok Sądu Najwyższego z dnia 11 kwietnia 2006 r., i PK 169/05, „Orzecznictwo Sądu Najwyższego Izba Pracy”, nr 7-8/2007, poz. 93.

${ }^{17}$ Wyrok Sądu Najwyższego z dnia 29 listopada 2012 r., II PK 112/12, „Monitor Prawa Pracy”, nr 4/2013, s. 197-199.

${ }^{18} \mathrm{~J}$. Wratny, Prawo do wynagrodzenia w świetle zasad sprawiedliwości i równości, http://phavi. umcs.pl/at/attachments/2015/0522/065217-referat-prof-wratny.pdf (dostęp: 06.11.2016).

${ }^{19}$ Wyrok Sądu Najwyższego z dnia 29 listopada 2012 r., II PK 112/12, „Monitor Prawa Pracy”, nr 4/2013, s. 197-199.

${ }^{20}$ Wyrok Sądu Najwyższego z dnia 3 czerwca 2014 r., III PK 126/13, Lex nr 1487089.
} 
być równo traktowani, lecz wskazują one jedynie na kryteria, które nie mogą uzasadniać różnicowania sytuacji zatrudnionych ${ }^{21}$.

Ta konkluzja wydaje się być uzasadniona zważywszy, że w pewnych przypadkach różnicowanie wynagrodzeń może być spowodowane przesłankami stażowymi, czy też strukturą terytorialną przedsiębiorstwa posiadającego oddziały $\mathrm{w}$ różnych częściach kraju - w takim przypadku dyferencjacja wynagrodzeń może znajdywać uzasadnienie w sytuacji na lokalnym rynku bądź w wysokości kosztów związanych z utrzymaniem na danym terenie i nie wykazywać związku z którymkolwiek z kryteriów dyskryminacyjnych ${ }^{22}$. Przykładowo SN w uzasadnieniu uchwały z dnia 27 marca 2007 r. wskazywał, że niekwestionowanym kryterium (miernikiem) nakładu pracy, któremu powinno odpowiadać wynagrodzenie za pracę (jego wysokość) jest staż pracy, czyli długość przyczyniania się pracownika (pracowników) do osiągnięcia pozytywnych efektów, zwłaszcza gospodarczych, pozwalająca na różnicowanie wysokości wynagrodzenia pracowniczego szczególnie w skali kwartału, czy roku ${ }^{23}$. Warto mieć jednak na uwadze, że różnicowanie wynagrodzeń pracowników ze względu na przykładowo staż pracy, wymaga przy ocenie zasadności zastosowania tego kryterium dużej ostrożności, gdyż bezkrytyczne odwołanie się do kryterium stażu pracy jako przyczyny uzasadniającej dyferencjację płacową, może prowadzić do utrwalania dyskryminacji kobiet ${ }^{24}$. Zgodnie z treścią art. $18^{3 a} \S 4$ k.p., z dyskryminacja pośrednią mamy do czynienia wtedy, gdy na skutek pozornie neutralnego postanowienia, zastosowanego kryterium lub podjętego działania występują lub mogłyby wystąpić niekorzystne dysproporcje albo szczególnie niekorzystna sytuacja w zakresie nawiązania i rozwiązania stosunku pracy, warunków zatrudnienia, awansowania oraz dostępu do szkolenia w celu podnoszenia kwalifikacji zawodowych wobec wszystkich lub znacznej liczby pracowników należących do grupy wyróżnionej ze względu na jedną lub kilka przyczyn określonych $\mathrm{w}$ art. $18^{3 \mathrm{a}} \S 1$ k.p., chyba że postanowienie, kryterium lub działanie jest obiektywnie uzasadnione ze względu na zgodny z prawem cel, który ma być osiągnięty, a środki służące osiągnięciu tego celu są właściwe i konieczne. Biorąc pod uwagę, że kobiety znacznie częściej niż mężczyźni legitymują się krótszym stażem pracy, odwołanie się do kryterium stażu pracy może prowadzić niekiedy do ich dyskryminacji, co stanowi nie tylko naruszenie zasady równego traktowania w zatrudnieniu, lecz także zwiększa ryzyko niższej

\footnotetext{
${ }^{21}$ Wyrok SN z dnia 14 maja 2014 r., II PK 208/13, Lex nr 1477443.

${ }^{22}$ J. Wratny, op. cit.

${ }^{23}$ Uchwała SN z dnia 27 marca 2003 r., II PZP 3/07, „Orzecznictwo Sądu Najwyższego Izba Pracy", nr 17-18/2007, poz. 243.

${ }^{24} \mathrm{~W}$ trakcie obrad poświęconych tematyce przestrzegania Konwencji Nr $111 \mathrm{MOP}$, podczas 83 sesji MPK w Genewie, wskazywano na konieczność dokonywania analiz w zakresie rozwiązań odnoszących się do stażu pracy celem ustalenia, które z nich utrwalają dyskryminację wobec osób legitymujących się często krótszym okresem, np. kobiet.
} 
emerytury, której wysokość w przypadku kobiet wynika zarówno z krótszego niż w przypadku mężczyzn stażu pracy, jak i z niższych zarobków, które z kolei mogą być konsekwencją utrwalania dyskryminacji płacowej kobiet spowodowanej odwoływaniem się do pozornie neutralnego postanowienia, jakim jest staż pracy.

Dlatego należy zgodzić się z prezentowanym w literaturze stanowiskiem wiążącym staż zawodowy z faktyczne posiadaną wiedzą i kwalifikacjami wykorzystywanymi na danym stanowisku, co prowadzi do wniosku, że powinien on również uwzględniać wykonywanie pracy w oparciu o niepracownicze podstawy zatrudnienia. W przypadku kobiet ma to szczególne znaczenie, gdyż słabsza $\mathrm{w}$ ich przypadku pozycja na rynku pracy prowadzi często do świadczenia pracy na podstawie umów cywilnoprawnych ${ }^{25}$.

Poza tym warto pamiętać, że pracownik może zgłosić okoliczności mogące wzbudzić poważne wątpliwości w przedmiocie zasadności odwołania się przez pracodawcę do stażu pracy, jako kryterium powiązanego z doświadczeniem, mającym wpływ na jakość pracy wykonywanej przez pracownika ${ }^{26}$. Dlatego tak jak podkreśla się w orzecznictwie i doktrynie, pracodawca powołujący się na różne kwalifikacje zawodowe i staż pracy musi wykazać, że miały one znaczenie przy wykonywaniu powierzonych pracownikom zadań ${ }^{27}$.

\section{Ubóstwo i wykluczenie społeczne kobiet w świetle danych organów UE}

Temat ubóstwa i wykluczenia społecznego kobiet stał się również przedmiotem zainteresowania Parlamentu Europejskiego. W uzasadnieniu sprawozdania z 26 kwietnia 2016 r., Komisja Praw Kobiet i Równouprawnienia wskazywała, że w 2015 r. pomimo poczynionych starań, osiągnięto niewielki postęp $\mathrm{w}$ walce $\mathrm{z}$ tym problemem ${ }^{28}$. Zgodnie $\mathrm{z}$ danymi statystycznymi dotyczącymi rozdziału ubóstwa dochodowego i nierówności dochodów w UE - 16,6\% ludności w 28 państwach członkowskich uznaje się za zagrożoną ubóstwem po transferach społecznych - przy czym w przypadku kobiet ryzyko to wynosi $17,2 \%$, zaś w przypadku mężczyzn 16,1\%. Zdaniem Komisji Praw Kobiet i Równouprawnienia, szczególnie zagrożone ubóstwem i wykluczeniem społecznym są kobiety niepełnosprawne, samotne matki, emerytki oraz imigrantki, gdyż to one znacznie częściej niż mężczyźni angażują się w opiekę nad człon-

\footnotetext{
${ }^{25} \mathrm{~K}$. Walczak, Staż pracy jako podstawa różnicowania wynagrodzenia pracowników - teoria i praktyka, „Monitor Prawa Pracy”, nr 3/2014, s. 122.

${ }^{26}$ C 17/05, „Monitor Prawa Pracy”, nr 11/2006, s. 619, podaję za: K. Walczak, op. cit., s. 122.

${ }^{27}$ Wyrok SN z 22 lutego 2007 r., I PK 242/06, „Orzecznictwo Sądu Najwyższego Izba Pracy”, nr 7-8, poz. 98.

${ }^{28}$ Sprawozdanie z 26 kwietnia 2016 r. w sprawie ubóstwa: perspektywa płci (2015/2228(INI)), http://www.europarl.europa.eu/sides/getDoc.do?pubRef=-//EP//NONSGML+REPORT+A82016-0153+0+DOC+PDF+V0//PL (dostęp: 30.10.2016).
} 
kami rodziny, co skutkuje przerwami w pracy zawodowej oraz prowadzi do wykonywania pracy w oparciu o pozapracownicze podstawy zatrudnienia, w ramach gospodarstwa domowego, w niepełnym wymiarze czasu pracy. Różnice $\mathrm{w}$ wynagrodzeniach oraz przerwy w karierze zawodowej spowodowane próbą pogodzenia życia zawodowego i prywatnego, prowadzą również do różnic w wysokości emerytur. Zgodnie z danymi Komisji Europejskiej, im krótszy jest staż pracy kobiety, tym dysproporcja w wysokości emerytur kobiet i mężczyzn jest wyższa i waha się od $18 \%$ do $33 \%$ na niekorzyść kobiet ${ }^{29}$.

\section{Renta rodzinna po zmarłym mężu a prawo kobiet do wypracowania wła- snej emerytury}

Kwestią istotną z punktu widzenia kobiet pracujących w gospodarstwie domowym jest również ocena instytucji renty rodzinnej, funkcjonującej na gruncie ustawy z dnia 17 grudnia 1998 r. o emeryturach i rentach z Funduszu Ubezpieczeń Społecznych $^{30}$. Regulacja zawarta $\mathrm{w}$ tej ustawie daje podstawę kobietom, które nie nabyły prawa do własnej emerytury i nie są w stanie same się utrzymać, możliwość ubiegania się o rentę rodzinną po zmarłym mężu, po spełnieniu przesłanek określonych $\mathrm{w}$ art. 70 u.e.r. Zgodnie $\mathrm{z}$ ust. 1 tego przepisu, wdowa ma prawo do renty rodzinnej, jeżeli:

- w chwili śmierci męża osiągnęła wiek 50 lat lub była niezdolna do pracy, albo

- wychowuje co najmniej jedno z dzieci, wnuków lub rodzeństwa uprawnione do renty rodzinnej po zmarłym mężu, które nie osiągnęło 16 lat, a jeżeli kształci się w szkole - 18 lat życia, lub jeżeli sprawuje pieczę nad dzieckiem całkowicie niezdolnym do pracy oraz do samodzielnej egzystencji lub całkowicie niezdolnym do pracy, uprawnionym do renty rodzinnej.

Co istotne w przypadku, gdy wdowa uzyska prawo do renty rodzinnej ze względu na osiągnięcie 50 roku życia, prawo do renty rodzinnej będzie miało charakter dożywotni.

Natomiast w sytuacji, gdy prawo do renty rodzinnej powstało nie ze względu na wiek, dojdzie do jego ustania w przypadku, gdy :

- wdowa odzyska zdolność do pracy - chyba że wychowuje osobę lub osoby, o których mowa w art. 70 ust. 1 pkt. 2,

- zaprzestanie wychowywania osób, o których mowa w art. 70 ust. 1 pkt 2,

\footnotetext{
${ }^{29}$ RPO: Niższe wynagrodzenia kobiet efektem nierówności w życiu społecznym, „Gazeta Prawna”, http://serwisy.gazetaprawna.pl/praca-i-kariera/artykuly/929539628,rpo-wynagrodzenia-kobiet-praca.html (dostęp: 30.10.2016).

${ }^{30}$ Ustawa z dnia 17 grudnia 1998 r. o emeryturach i rentach z Funduszu Ubezpieczeń Społecznych, Dz.U. z 1998 r. Nr 162, poz. 1118 ze zm.
} 
- zaprzestanie sprawowania pieczy nad dzieckiem, o którym mowa w art. 70 ust. 1 pkt 2,

- prawo do renty rodzinnej nabędzie również wdowa, która osiągnęła wiek 50 lat lub stała się niezdolna do pracy po śmierci męża, nie później jednak niż w ciągu 5 lat od jego śmierci lub od zaprzestania wychowywania osób, o których mowa w art. 70 ust. 1 pkt. 2 (art. 70 ust. 2 u.e.r.).

Podkreślenia wymaga również, że rozwód będący skutkiem trwałego i zupełnego rozkładu pożycia małżeńskiego, nie przekreśla prawa kobiety do renty rodzinnej po zmarłym mężu.

Ten przypadek ustawodawca uregulował w art. 70 ust. 3 u.e.r. stanowiąc, że prawo do renty rodzinnej ma również małżonka rozwiedziona lub wdowa, która do dnia śmierci męża nie pozostawała z nim we wspólności małżeńskiej, jeżeli spełnia warunki określone w art. 70 ust. 1 lub 2, a dodatkowo również w dniu śmierci męża miała prawo do alimentów z jego strony ustalone wyrokiem lub ugodą sądową.

Natomiast w sytuacji, gdy wdowa nie spełnia warunków określonych w art. 70 ust. 1 lub 2 u.e.r. może ubiegać się o rentę rodzinną mającą charakter okresowy, jeżeli nie posiada niezbędnych źródeł utrzymania.

Renta rodzinna, o której stanowi art. 70 ust. 4 u.e.r. ma charakter okresowy, gdyż może zostać przyznana tylko na okres jednego roku od chwili śmierci męża, chyba że wdowa uczestniczy w zorganizowanym szkoleniu mającym na celu uzyskanie kwalifikacji do pracy zarobkowej - wówczas okres pobierania renty rodzinnej może zostać wydłużony maksymalnie na okres dwóch lat od chwili śmieci męża.

Nie wdając się w szczegóły dotyczące regulacji renty rodzinnej należy zauważyć, że instytucja ta odzwierciedla istniejącą dyskryminację płacową kobiet. Jej wysokość uzależniona jest od wysokości emerytury lub renty z tytułu niezdolności do pracy, która przysługiwałaby osobie zmarłej, co oznacza, że funkcjonuje ona $\mathrm{w}$ oderwaniu od wartości pracy wykonywanej w ramach prowadzenia gospodarstwa domowego, którą należy szacować nie tylko w liczbach, lecz również uwzględniać jej znaczenie w kształtowaniu rozwoju całego społeczeństwa. Co więcej, często pobieranie renty rodzinnej jest dla kobiet korzystniejsze niż pobieranie własnej emerytury lub renty z tytułu niezdolności do pracy, co wiąże się z wysokością przeciętnego wynagrodzenia osiąganego przez mężczyzn - na ogół jest ono wyższe niż wynagrodzenie pobierane przez kobiety ${ }^{31}$. Zgodnie z danymi GUS w październiku 2014 r. przeciętne wynagrodzenie mężczyzn było wyższe niż wynagrodzenie kobiet o 764,18 zł (tj.o 20.6\%). Mężczyźni osiągnęli wynagrodzenie o 374,03 zł (tj. o 9,1\%) wyższe od średniego

\footnotetext{
${ }^{31}$ Zakład Ubezpieczeń Społecznych. Departament Statystyki i Prognoz Aktuarialnych, Struktura wysokości emerytur i rent wypłacanych przez ZUS po waloryzacji w marcu 2016 r., Serwis Informacyjny ZUS - strona główna, http://www.zus.pl/documents/ (dostęp: 17.04.2017).
} 
w skali kraju, natomiast kobiety niższe o 390,15 zł (tj. o 9,5\%) niższe ${ }^{32}$. Tak więc wdowy uprawnione do renty rodzinnej po zmarłym mężu, często znajdują się w korzystniejszej sytuacji materialnej niż te, które pracując zawodowo, nabyły prawo do własnej emerytury. Wynika to, tak jak zostało to wcześniej wskazane, zazwyczaj z krótszego niż w przypadku mężczyzn stażu pracy, a także niższego wynagrodzenia, które ma wpływ na wysokość składek odprowadzanych na ubezpieczenie społeczne.

\section{Podsumowanie}

Tytułem podsumowania warto wskazać, że praca kobiet w gospodarstwie domowym jest dużym wyzwaniem dla prawa pracy i prawa ubezpieczeń społecznych. Badania dotyczące budżetu czasu ludności wskazują, że to kobiety częściej niż mężczyźni poświęcają czas obowiązkom, również tym związanym z zajęciami i pracami domowymi. Natomiast udział czasu odpoczynku w strukturze doby kobiety jest na wszystkich etapach cyklu życia niższy niż u mężczyzn. Warto podkreślić, że istotne różnice w strukturze doby kobiet i mężczyzn, zaobserwowano w odniesieniu do dwóch grup czynności zaliczanych do czasu obowiązku - pracy zawodowej oraz zajęć i prac związanych z prowadzeniem gospodarstwa domowego. Wypełnianie obowiązków domowych pochłaniało zdecydowane większą część doby w przypadku kobiet, mniejsza jej część poświęcały z kolei na pracę zawodową ${ }^{33}$.

Prace przynależące do sfery prywatnej, chociaż posiadają wartość rynkową nie są opłacane, a to ma wpływ nie tylko na sytuację materialną kobiet i ich zabezpieczenie emerytalne, lecz również na występowanie przemocy, której ofiarami stają się przede wszystkim kobiety, uzależnione ekonomicznie od mężów. Dlatego tak ważne jest, aby wreszcie dostrzec wagę i skalę problemu, jakim jest brak odpowiednich rozwiązań systemowych i prawnych, zmierzających do poprawy sytuacji kobiet pracujących w domu ${ }^{34}$.

Wydaje się, że jeszcze przez długi czas nie uda się wypracować satysfakcjonujących rozwiązań przede wszystkim ze względu ścieranie się dwóch wartości: $\mathrm{z}$ jednej strony praca kobiet $\mathrm{w}$ domu, które całkowicie poświęciły się rodzinie oraz praca kobiet na podwójnym, potrójnym, a czasem nawet poczwórnym „eta-

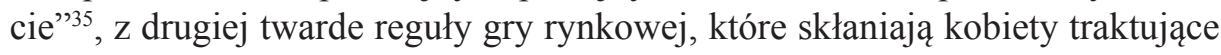
karierę zawodową jako priorytet, do całkowitego oddania się pracy zarobkowej,

\footnotetext{
${ }^{32}$ Główny Urząd Statystyczny, Struktura wynagrodzeń, op. cit.

${ }^{33}$ Główny Urząd Statystyczny, Departament Badań Społecznych i Warunków Życia, Budżet czasu ludności 2013. Cz. II, Warszawa 2016 r.; I. Błaszczak-Przybycińska, op. cit.

${ }^{34}$ Por. dane dotyczące głównych przyczyn związanych z usługami opiekuńczymi dla dzieci do lat 14 wpływające na niepodejmowanie pracy lub pracę w niepełnym wymiarze czasu pracy, [w:] Główny Urząd Statystyczny, Praca a obowiązki...

${ }^{35} \mathrm{~J}$. Szachowicz-Sempruch, op. cit.
} 
co wskazuje przede wszystkim na potrzebę rozwijania zinstytucjonalizowanych form opieki nad dziećmi oraz wspieranie ich aktywności na rynku pracy. Bez wątpienia, praca domowa ma dużą wartość, także ekonomiczną, ale uważam, że regulacja prawna pracy wykonywanej w gospodarstwie domowym powinna stanowić tylko pomocnicze rozwiązanie tego problemu zwłaszcza, że należałoby się zastanowić jak oszacować wartość pracy, wykonywanej przez kobiety w domu w poszczególnych przypadkach. To zaś rodzi pytanie o możliwość i sposób ewidencjonowania godzin pracy, świadczonej przez kobiety w domu (patrząc na ten problem choćby z perspektywy ochrony dóbr osobistych, takich jak np. godność, prawo do prywatności, pojawia się pytanie kto, w jakim zakresie byłby uprawniony do kontroli rzeczywistego wykonywania poszczególnych zajęć i prac domowych). Uczestnicy badań wskazują bowiem trafnie, że nie wszystkie kobiety są jednakowo obciążone taką pracą ${ }^{36}$. Są to zresztą nie jedyne zagrożenia, które wiążą się z opłacaniem pracy wykonywanej w gospodarstwie domowym $^{37}$. Wskazuje się również, że płaca za pracę w domu mogłaby wpłynąć niekorzystnie na zmianę stosunków pomiędzy małżonkami, gdyż mężowie mogliby utwierdzić się w przekonaniu, iż mają prawo oczekiwać od żon prac domowych, ze względu na ich opłacanie z budżetu państwa. Układ polegający na opłacaniu $z$ budżetu państwa prac domowych wykonywanych przez kobiety na rzecz mężów i innych członków rodziny, doprowadziłby do przekształcenia typowych dla społeczeństwa patriarchalnego relacji w legitymizowany patriarchat państwowy. Ponadto pojawia się pytanie, czy również mężczyźni wykonujący prace w ramach gospodarstwa domowego, nie powinni otrzymywać w zamian wynagrodzenia z budżetu państwa.

Moim zdaniem państwo powinno więc przede wszystkim zmierzać do zagwarantowania kobietom obok równych praw, także realizację dyrektyw: równego traktowania oraz równych szans ${ }^{38}$. Przede wszystkim należy podjąć działania mające na celu wyeliminowanie zjawiska dyskryminacji płacowej, co w konsekwencji wpłynie na wysokość emerytur kobiet oraz w połączeniu $\mathrm{z}$ upowszechnianiem modelu rodziny opartym na partnerstwie i sprawiedliwym podziale obowiązków domowych, może przyczynić się do większej aktywności kobiet na rynku pracy.

Biorąc pod uwagę powyższe rozważania, skłaniam się raczej do postulatu wzmacniania potencjału zawodowego kobiet na rynku pracy poprzez tworzenie warunków umożliwiających rodzicom godzenie życia zawodowego z rodzinnym. Priorytetem państwa powinna być więc nie regulacja prawna pracy wykonywanej w domu, lecz przede wszystkim inwestycja w rozbudowę zinstytucjonalizowanego systemu opieki nad dziećmi, aktywizacja zawodowa kobiet

\footnotetext{
${ }^{36}$ A. Titkow, D. Duch-Krzystoszek, B. Budrowska, op. cit., s. 148.

${ }^{37}$ Ibidem, s. 147-148.

${ }^{38}$ U. Jackowiak, op. cit., s. 21-31.
} 
w każdym wieku, również starszych, których stan zdrowia i motywacja pozwalają na wykonywanie pracy zawodowej i czerpanie z niej satysfakcji. Szczególnie istotne jest to $\mathrm{w}$ kontekście prognozowanych zmian demograficznych oraz zmian struktury demograficznej kraju ${ }^{39}$. Ważne jest również kształtowanie wśród kobiet idei kształcenia ustawicznego, co znacznie zwiększy ich szanse na rozwój zawodowy i osobisty, wzmocni pozycję negocjacyjną względem pracodawcy, a tym samym umożliwi zachowanie równowagi $\mathrm{w}$ sferze życia zawodowego i osobistego.

\section{Bibliografia}

\section{Literatura}

Baran K.W. (red.), Kodeks pracy. Komentarz, Warszawa 2016.

Dryjańska A., Piotrowska J. (red.), Nieodpłatna praca kobiet: różowa strefa gospodarki, Warszawa 2012.

Jackowiak U., Sytuacja pracownicza kobiet, Gdańsk 1994.

Titkow A. ,Duch-Krzystoszek D., Budrowska B., Nieodpłatna praca kobiet. Mity, realia, perspektywy, Warszawa 2004.

Walczak K., Staż pracy jako podstawa różnicowania wynagrodzenia pracowników - teoria i praktyka, ,Monitor Prawa Pracy” 2014, nr 3.

\section{Akty prawne}

Konstytucja Rzeczypospolitej Polskiej z dnia 2 kwietnia 1997 r., Dz.U. z 1997 r. Nr 78, poz. 483 ze zm.

Ustawa z dnia 17 grudnia 1998 r. o emeryturach i rentach z Funduszu Ubezpieczeń Społecznych, Dz.U. z 1998 r. Nr 162, poz. 1118 ze zm.

Ustawa z dnia 26 czerwca 1974 r. Kodeks pracy, tekst jedn. Dz.U. z 2016 r., poz. 1666.

\section{Orzeczenia sądowe}

Uchwała Sądu Najwyższego z dnia 27 marca 2003 r., II PZP 3/07, „Orzecznictwo Sądu Najwyższego Izba Pracy", nr 17-18/2007, poz. 243.

Wyrok Sądu Najwyższego z 22 lutego 2007 r., I PK 242/06, „Orzecznictwo Sądu Najwyższego Izba Pracy", nr 7-8, poz. 98.

Wyrok Sądu Najwyższego z dnia 11 kwietnia 2006 r., I PK 169/05, „Orzecznictwo Sądu Najwyższego Izba Pracy", nr 7-8/2007, poz. 93.

Wyrok Sądu Najwyższego z dnia 14 maja 2014 r., II PK 208/13, Lex nr 1477443.

Wyrok Sądu Najwyższego z dnia 29 listopada 2012 r., II PK 112/12, „Monitor Prawa Pracy”, nr 4/2013, s. 197-199.

Wyrok Sądu Najwyższego z dnia 3 czerwca 2014 r., III PK 126/13, Lex nr 1487089.

\footnotetext{
${ }^{39}$ Prognoza ludności na lata 2014-2050, Główny Urząd Statystyczny, Portal Informacyjny, http:// stat.gov.pl/obszary-tematyczne/ludnosc/prognoza-ludnosci/prognoza-ludnosci-na-lata-20142050-opracowana-2014-r-, 1,5.html (dostęp: 14.11.2016).
} 


\section{Źródla internetowe}

Błaszczak-Przybycińska I., Wartość pracy domowej - wycena empiryczna na podstawie ogólnopolskiego badania budżetu czasu ludności, http://search.ebscohost.com.ebscohostresearchdatabasestest0.han3.lib.uni.lodz.pl.ebscohostresearchdatabasestest0.han3.lib. uni.lodz.pl (dostęp: 09.04.2017).

Główny Urząd Statystyczny, Kobiety i mężczyźni na rynku pracy 2016, Główny Urząd Statystyczny. Portal Informacyjny, http://stat.gov.pl/obszary-tematyczne/rynek-pracy/ (dostęp: 17.04.2017).

Główny Urząd Statystyczny, Praca a obowiązki rodzinne w 2010 r., Główny Urząd Statystyczny. Portal Informacyjny, http://stat.gov.pl/obszary-tematyczne/rynek-pracy/ (dostęp: 17.04.2017).

Główny Urząd Statystyczny, Prognoza ludności na lata 2014-2050, Główny Urząd Statystyczny, Portal Informacyjny, http://stat.gov.pl/obszary-tematyczne/ludnosc/prognoza-ludnosci (dostęp: 14.11.2016).

Główny Urząd Statystyczny, Różnice $w$ wynagrodzeniach kobiet i mężczyzn w Polsce (stan w 2014 roku), Główny Urząd Statystyczny. Portal Informacyjny, http://stat.gov.pl/ obszary-tematyczne/rynek-pracy (dostęp: 17.04.2017).

Główny Urząd Statystyczny, Struktura wynagrodzeń wedtug zawodów w październiku 2014 r., Główny Urząd Statystyczny. Portal Informacyjny, http://stat.gov.pl/obszary-tematyczne/rynekpracy (30.10.2016).

Główny Urząd Statystyczny. Departament Badań Społecznych i Warunków Życia, Budżet czasu ludności 2013. Cz. II, Warszawa 2016 r., https://stat.gov.pl/download/ (dostęp: 09.04.2017).

http://search.ebscohost.com.ebscohostresearchdatabasestest0.han3.lib.uni.lodz.pl.ebscohostresearchdatabasestest0.han3.lib.uni.lodz.pl (dostęp: 09.04.2017).

http://stat.gov.pl/obszary-tematyczne/ludnosc/prognoza-ludnosci (14.11.2016).

http://www.zus.pl/documents/ (dostęp: 17.04.2017).

Lisowska E., Przemoc ekonomiczna wobec kobiet, Obserwatorium Równości Płci, http://rownoscplci.pl/uploads/ (dostęp: 09.04.2017).

Marszałek M., Rola kobiet i mężczyzn w tworzeniu nierynkowej produkcji gospodarstw domowych - rekomendacje dla polityki rodzinnej, http://search.ebscohoust.com.ebscohuostresearchdatabasestest0.han3.lib.uni.lodz.pl (dostęp: 09.04.2017).

RPO: Niższe wynagrodzenia kobiet efektem nierówności w życiu społecznym, Gazeta Prawna, http://serwisy.gazetaprawna.pl/praca-i-kariera/ (dostęp: 30.10.2016).

Sprawozdanie z 26 kwietnia 2016 r. w sprawie ubóstwa: perspektywa płci (2015/2228(INI)), http://www.europarl.europa.eu/sides/getDoc (dostęp: 30.10.2016).

Szachowicz-Sempruch J., Nieodplatna praca $w$ domu i polityka rodzinna jako formy przemocy instytucjonalnej, http://search.ebscohost.com.ebscohostresearchdatabasestest0.han3. lib.uni.lodz.pl (dostęp: 09.04.2017).

Wratny J., Prawo do wynagrodzenia w świetle zasad sprawiedliwości i równości, http://phavi. umcs.pl/at/attachments/ (dostęp: 06.11.2016).

Zakład Ubezpieczeń Społecznych. Departament Statystyki i Prognoz Aktuarialnych, Struktura wysokości emerytur i rent wypłacanych przez ZUS po waloryzacji w marcu 2016 r., Serwis Informacyjny ZUS - strona główna, http://www.zus.pl/documents/ (dostęp: 17.04.2017). 